УДК 661.728.86

\title{
ХИМИЧЕСКАЯ МОДИФИКАЦИЯ АЗОТНОКИСЛЫХ ЭФИРОВ ЦЕЛЛЮЛОЗЫ (ОБЗОР)
}

\author{
(C) С.М. Романова, А.М. Мадякина, Д.И. Сабирова", М.В. Хузеев \\ Казанский национальный исследовательский технологический университет, \\ ул. Карла Маркса, 68, Казань, 420015 (Россия), e-mail: dinka-sab@mail.ru
}

Обобщены и систематизированы литературные данные последних лет о реакциях нитратов целлюлозы с различными реагентами, протекающих по донорно-акцепторному, радикальному механизмам, приведены схемы вероятных направлений взаимодействия с нуклеофилами и электрофилами. Особенности химического строения макромолекул азотнокислых эфиров целлюлозы обусловливают возможность химических превращений по различным реакционным центрам ее элементарного звена: реакции по нитратным группам, реакции по имеющимся свободным гидроксилам и реакции по гликозидным связям, всегда приводящие к деструкции полимерной цепи. Обзор научной и патентной литературы, касающейся этого вопроса, свидетельствует о том, что обычно при действии на НЦ химических реагентов различного характера, а также света и тепла наблюдаются в той или иной степени одновременно все три типа реакций, причем реакционная способность каждого из центров находится в прямой зависимости от соседнего окружения в элементарном звене, изменяющемся в процессе.

Ключевые слова: модификация, нитрат целлюлозы, переэтерификация, реакционноспособность.

Нитраты целлюлозы (НЦ) - одни из первых искусственных полимеров, полученных из природного растительного сырья, которые нашли широкое применение в промышленности. Азотнокислые эфиры целлюлозы могут стать тем полупродуктом, на основе которого путем его модификации по реакции этерификации гидроксильных групп, переэтерификации нитратных групп возможно целенаправленное изменение практически важных свойств полимера в результате образования новых производных целлюлозы $[1,2]$.

НЦ - это стереорегулярный полимер, элементарные звенья которого представляют собой не полностью этерифицированные по гидроксильным группам азотной кислотой остатки $D$-ангидроглюкозы, со-

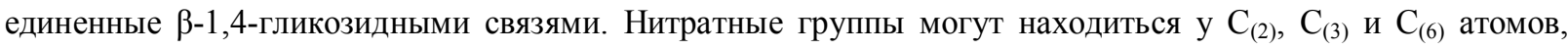
причем две из них при вторичном атоме углерода, одна - при первичном [3]. Реально говоря о положении нитратных групп в замещенном кольце, следует иметь в виду, что сложноэфирные группы расположены в нем не статистически и, по данным ряда авторов, изучавших спектры ЯМР ${ }^{13} \mathrm{C}$ НЦ различной степени замещения, их распределение у $\mathrm{C}_{(2)}, \mathrm{C}_{(3)}$ и $\mathrm{C}_{(6)}$ отвечает соотношению $1,8: 1,06: 5,8$ [4-6].

Особенности химического строения макромолекул НЦ позволяют предполагать возможность химических превращений по различным реакционным центрам его элементарного звена: реакции по нитратным группам, реакции по имеющимся свободным гидроксилам и реакции по гликозидным связям, всегда при-

Романова Светлана Марсельевна - кандидат химических наук, доцент кафедры «Инженерная экология», e-mail: romsvetlana80@mail.ru Мадякина Альмира Мустакимовна - кандидат химических наук, доцент кафедры «Инженерная экология», e-mail: almi_almi@mail.ru Сабирова Динара Илнуровна - аспирант, e-mail: dinka-sab@mail.ru

Хузеев Марсель Валеевич - доктор технических наук, профессор кафедры «Химия и технология высокомолекулярных соединений», e-mail:dinka-sab@mail.ru водящие к деструкции полимерной цепи. Обзор научной и патентной литературы, касающейся этого вопроса, свидетельствует о том, что обычно при действии на НЦ химических реагентов различного характера, а также света и тепла наблюдаются в той или иной степени одновременно все три типа реакций, причем реакционная способность каждого из центров находится в прямой зависимости от соседнего окружения в элементарном звене, изменяющемся в процессе.

\footnotetext{
* Автор, с которым следует вести переписку.
} 
За последние годы разработаны направленные методы химических модификаций НЦ: реакции нуклеофильного, электрофильного замещения нитратных и гидроксильных групп и радикального присоединения [7].

\section{Реакции НЦ с нуклеофилами}

При нуклеофильном замещении нуклеофил ( $\mathrm{Nu}$ ) атакует атомы в молекуле полимера, предоставляя им для образования новой связи свои электроны. Электроны разрывающейся связи уходят вместе с освобождающимся ионом [8].

В реакциях нуклеофильного замещения применительно к НЦ участвуют нитратные группы, так как они более поляризованы, чем гидроксильные [9].

В присутствии веществ основного характера (гидроокисей и окисей

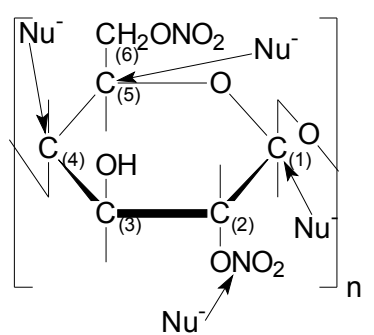
металлов, солей слабых кислот, аминов и др.) НЦ могут претерпевать ряд химических превращений, ведущих не только к потере связанного азота, деструкции основной цепи макромолекулы, но и глубокому дальнейшему разрушению азотнокислых эфиров целлюлозы, в результате которого образуются мономерные окисленные фрагменты целлюлозы и неорганические вещества [10]. Наибольшее разрушающее действие на НЦ оказывают щелочи; в присутствии кислорода воздуха они вызывают глубокое окислительное разложение нитрата с образованием альдегидов, кетонов, солей органических, азотной и азотистой кислот $[11,12]$.

Добавление $\mathrm{NaOH}$ и КОН к растворам НЦ в ацетоне резко уменьшает их вязкость, причем в зависимости от условий в большей или меньшей степени протекает и процесс денитрования. Исследования химического состава гидролизата щелочного омыления нитрозоэфиров многоатомных спиртов, включая и целлюлозу, выявило наличие в нем ионов $\mathrm{NH}_{4}{ }^{+}, \mathrm{CN}^{-}, \mathrm{NO}_{3}{ }^{-}, \mathrm{NO}_{2}^{-}[13]$.

Процессы, протекающие в НЦ под влиянием щелочей, можно представить в виде [13-18]:

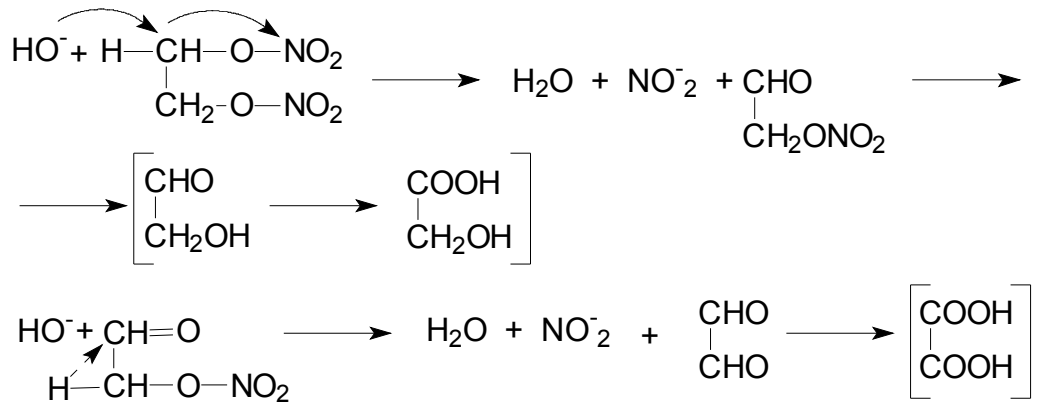

В процессе щелочного омыления нитратов и других эфиров целлюлозы наряду с этой реакцией имеет место и внутримолекулярное нуклеофильное замещение по схеме:

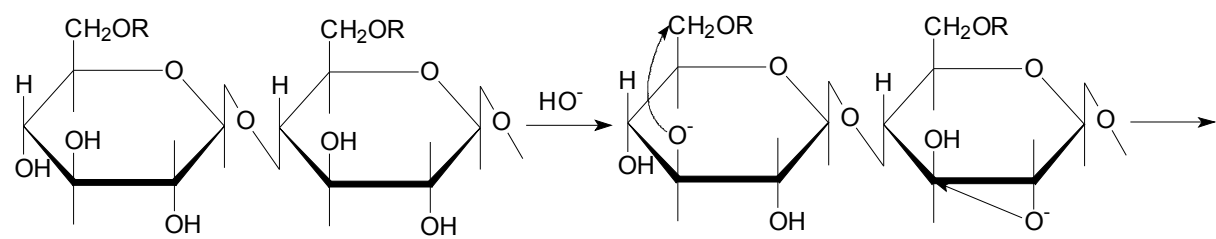

(R: $\left.-\mathrm{NO}_{2},-\mathrm{SO}_{3} \mathrm{H},-\mathrm{PO}_{3} \mathrm{H}\right)$

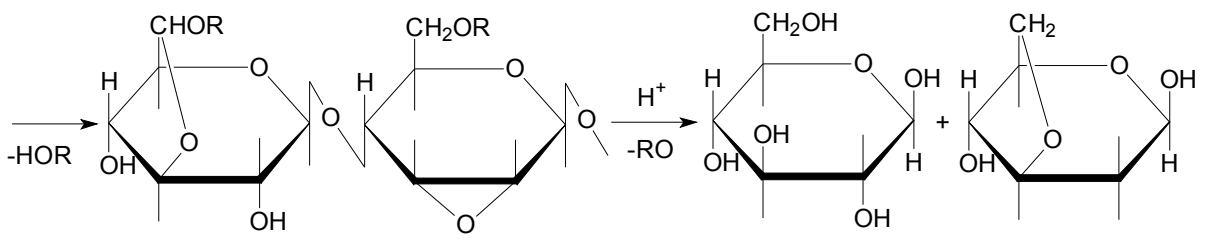

Денитрование гидросульфидами щелочных металлов или аммония, особенно в спиртовой среде, нашло широкое применение для мягкого удаления нитратных групп из азотнокислых эфиров целлюлозы. 
Реакция имеет много различных модификаций $[19,20]$, ставивших целью в первую очередь снижение уровня деструктивных процессов, а также упрощение выделения и очистки денитрованного полимера. Исследование механизма процесса денитрования при обработке азотнокислых эфиров сульфидами и гидросульфидами щелочных металлов и аммония показало, что процесс представляет собой многостадийную цепь взаимосвязанных реакций, в результате которой регенерируется гидроксильная группа, выделяется сера в виде сульфида или полисульфида, азот выделяется в форме нитрит-иона или аммиака, образующегося в результате взаимодействия нитрита с $\mathrm{H}_{2} \mathrm{~S}$.

При $p H$ больше 13 гидросульфиды восстанавливают нитрат до нитрита с выделением 1 г атома серы [21]. Реакция представляет собой автокаталитический процесс, обусловленный ионами полисульфида и гидроксилов, и описывается уравнением для реакций второго порядка. При этом регенерации подвергаются азотнокислые группы во всех трех положениях - у $\mathrm{C}_{(2)}, \mathrm{C}_{(3)}$ и $\mathrm{C}_{(6)}$ [22].

Относительную реакционную способность первичных и вторичных нитратных групп целлюлозы изучали, омыляя эфир спиртовым раствором $\mathrm{NH}_{3}$ [23], и определяли содержание общего азота и нитратных групп, находящихся при вторичных углеродных атомах, методом йодирования. Показано, что денитрованию в первую очередь подвергаются вторичные нитратные группы, т.е. нитратные группы при $\mathrm{C}_{(2)}$ и $\mathrm{C}_{(3)}$, которые обладают в щелочной среде повышенной реакционной способностью по сравнению с $\mathrm{C}_{(6)}-\mathrm{ONO}_{2}$.

В литературе описано [24] взаимодействие НЦ с раствором гидроксиламина, который обладает слабоосновными свойствами, поэтому его растворы позволяют снижать степень полимеризации и содержание азота в НЦ, сохраняя прежнюю морфологическую структуру продукта. Гидроксиламин взаимодействует с нитратными группами молекулы НЦ:

$$
\left[\mathrm{C}_{6} \mathrm{H}_{7}\left(\mathrm{ONO}_{2}\right)_{3}\right]_{\mathrm{n}}+\mathrm{n} 5 \mathrm{NH}_{2} \mathrm{OH} \longrightarrow\left[\mathrm{C}_{6} \mathrm{H}_{7}\left(\mathrm{ONO}_{2}\right)_{3-\mathrm{x}}(\mathrm{OH})_{\mathrm{x}}\right]_{\mathrm{n}}+\mathrm{n} 3 \mathrm{~N}_{2}+\mathrm{n} 7 \mathrm{H}_{2} \mathrm{O}
$$

При действии ацетиленида натрия или амидов калия и натрия $[25,26]$ на НЦ в среде жидкого аммиака возможно образование аминодезоксипроизводного. При этом амиды, реагируя с растворенными в жидком аммиаке НЦ различной степени замещения, приводят к синтезу только моноаминопроизводного. Относительная устойчивость диазотированной аминодезоксицеллюлозы позволила сделать вывод, что на аминогруппу замещаются только вторичные $\mathrm{ONO}_{2}$-группы, а $\mathrm{C}_{(6)}-\mathrm{ONO}_{2}$ подвержена в этих условиях лишь аммонолизу. Реакция протекает по схеме:

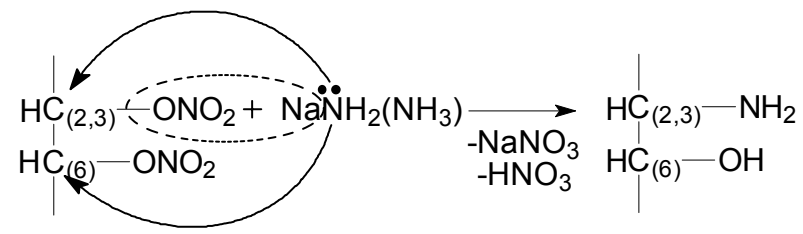

Ацетиленид натрия в жидком аммиаке, действуя на НЦ, образует смешанное аминопроизводное целлюлозы, в элементарном звене которой, помимо аминогруппы, находится и этинильная.

Амины (первичные, вторичные) и особенно ароматические аминокислоты также вступают в реакцию нуклеофильного замещения с НЦ с образованием N-замещенных дезоксиаминопроизводных целлюлозы [27].

В качестве таких нуклеофильных реагентов были изучены некоторые аминокислоты - иминодиуксусная, антраниловая кислота и ее пара- и мета-изомеры, а также о-аминофениларсиновая и о-аминофенилсульфоновая (ортаниловая) кислоты. Были получены продукты со степенью замещения (C3) по дезоксиаминогруппам около 2. Наиболее активно с $\mathrm{ONO}_{2}$-группами реагирует о-аминобензойная кислота. Так, через 9 ч при $120^{\circ} \mathrm{C}$ достигается практически количественное замещение имевшихся нитратных групп на остатки антраниловой кислоты: при содержании нитратного азота в исходном полимере $11,7 \%$. В этих же условиях с $n$-аминобензойной кислотой образуется продукт со С3 1,40. Еще медленнее реагирует мета-изомер. Таким образом, по способности к реакции нуклеофильного замещения нитратных групп азотнокислых эфиров целлюлозы аминобензойные кислоты располагаются в ряд: орто- > пара- > мета-. Также в 1975 году японскими учеными [28] были изучены реакции НЦ с калиевой солью п-аминобензойной кислоты (ПАБК) и диэтиламмониевой солью ПАБК. 
В работах Н.В. Степановой сообщается о взаимодействии НЦ с анилином [29]. Реакция НЦ, с содержанием азота 13,05\%, с основанием средней силы - анилином ( $\left.p K_{b}=4,6\right)$, осуществлялась в гомогенной среде ДМФА. Атом азота аминогруппы анилина, имея повышенную электронную плотность, атакует углеродные атомы НЦ. Наибольшей степени замещения нитратных групп на фениламинный фрагмент $(\mathrm{C} 3=1,6)$ удалось достичь при проведении реакций в интервале температур 96-98 ${ }^{\circ} \mathrm{C}$. Для интенсификации взаимодействия добавлялся пиридин в качестве так называемого «щелочного катализатора».

Автором [30] были получены аминонитратпроизводные целлюлозы реакцией НЦ с щелочными растворами аминокислот (лизина и глицина). Модификация осуществлялась двумя способами [30]. Первый способ основывался на том факте, что нитратные группы, как и галогенфункциональные группы, чувствительны к нуклеофильным атакам аминов. Второй способ базировался на том, что гидроксигруппы на атомах углерода $\mathrm{C}_{(2)}$ и $\mathrm{C}_{(3)}$ НЦ могут быть окислены йодной кислотой и ее солями до диальдегидных структур. К образовавшимся диальдегидным группам с помощью $\mathrm{NaCNBH}_{3}$ в восстановительном процессе аминирования присоединяли аминокислоты.

Третичные амины оказывают в основном деструктирующее действие, что отражается на вязкости полимера [31]. Добавка в сухой пиридин гидроксиламина, который сам по себе вызывает лишь незначительное изменение в химическом составе НЦ, приводит уже при комнатной температуре к реакции по нитратным группам с выделением газообразных продуктов [32, 33]. Тринитрат целлюлозы в сухом пиридине, содержащем избыток гидроксиламина, также претерпевает частичное денитрование с выделением азота и образованием продукта, содержащего на одно звено 1,7 нитратных группы и 0,08 оксимных [33]. Замена $\mathrm{NH}_{2} \mathrm{OH}$ на $\mathrm{NH}_{2} \mathrm{OH} \cdot \mathrm{HCl}$ изменяет механизм реакции, и выделенный волокнистый продукт представляет собой оксимдинитрат целлюлозы (С3 по оксимным группам составляет 1, по нитратным - 1,7). Реакция идет с преимущественным образованием оксимной группировки у $\mathrm{C}_{(2)}$-атома элементарного звена [36].

В литературе имеются данные [34] о взаимодействии НЦ (содержание азота 11,56\%) с несимметричным диметилгидразином (НДМГ) и его гидразидами. Степень замещения по $\mathrm{NHN}\left(\mathrm{CH}_{3}\right)_{2}$-группам в получаемых продуктах составила 0,90-0,92. В этих же условиях с диметилгидразидом фталевой кислоты образуется продукт со СЗ всего лишь 0,12 .

Известны реакции НЦ с циклическими соединениями, например, Н.П. Логинов и С.Н. Логинова [35] предлагают модифицировать высокоазотный НЦ капролактамом, в результате чего происходит замещение нитратных групп с раскрытием цикла капролактама:

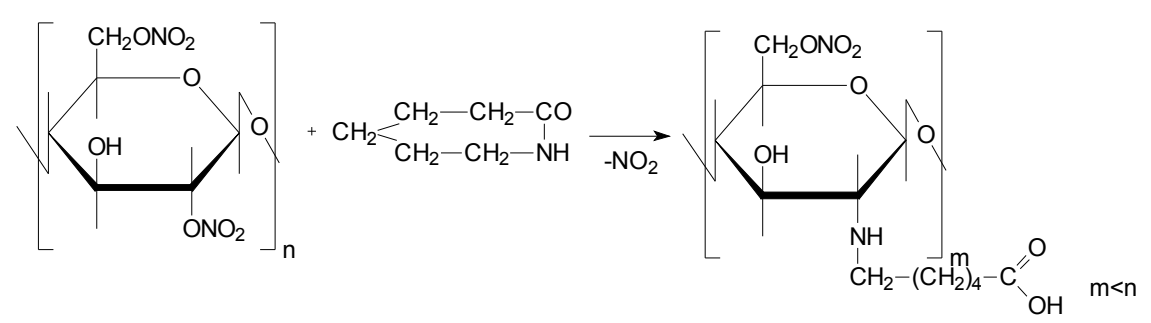

Степень замещения на фрагмент капролактама в получаемых продуктах, рассчитанная по содержанию СООН-групп, составила 0,1-1,0.

Йодистый натрий действует на первичные нитроэфирные группы НЦ [36-48] с количественным замещением $\mathrm{C}_{(6)}-\mathrm{ONO}_{2}$ на атом йода, давая 6-йод-дезоксицеллюлозу. Эта реакция, протекающая по нижеприведенной схеме, представляет собой пример нуклеофильного замещения нитратной группы:

$$
\left[\mathrm{C}_{6} \mathrm{H}_{7}(\mathrm{OH})_{3-\mathrm{x}}\left(\mathrm{ONO}_{2}\right)_{\mathrm{x}}\right]_{\mathrm{n}}+\mathrm{nzNaI} \longrightarrow\left[\mathrm{C}_{6} \mathrm{H}_{7}\left(\mathrm{ONO}_{2}\right)_{\mathrm{x}-\mathrm{z}}(\mathrm{OH})_{3-\mathrm{x}}(\mathrm{I})_{\mathrm{z}}\right]_{\mathrm{n}}+\mathrm{nzNaNO} \mathrm{n}_{3}, \mathrm{z}<1
$$

Другие галоиды щелочных металлов $\mathrm{LiCl}, \mathrm{KBr}, \mathrm{NaI}$ также вступают в реакцию нуклеофильного замещения с НЦ [38, 39]. Образующиеся в результате реакций галогендезоксицеллюлозы, в частности йоддезоксипроизводные [40, 41], далее могут быть обработаны 9\% спиртовым раствором КОН. В результате образуется полимер, практически не содержащий йод и нитратные группы и представляющий собой смешанный полисахарид, в состав которого входят звенья 5,6-глюкозина (35-40\% на 1 моль), 3,6-ангидро- $D$ глюкозы (35-40\%) и глюкозы (10-20\% на 1 моль): 


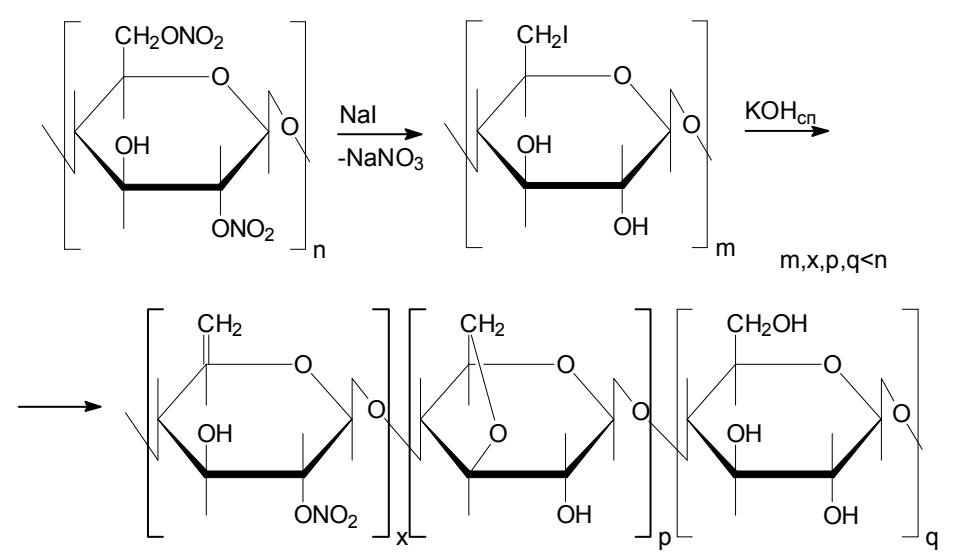

Фториды щелочных металлов, вопреки ожидаемому эффекту, дают в условиях получения йоддезоксисоединений продукты нуклеофильного замещения лишь со С3 0,05-0,06. Об образовании фтордезоксипроизводных НЦ с более высокой С3 по фтору имеется лишь одно сообщение в патентной литературе [42]. Фториды получали действием $\mathrm{SF}_{4}$ при температуре, меньшей или равной $70{ }^{\circ} \mathrm{C}$ в газовой фазе или в суспензии. В зависимости от времени и температуры реакции С3 нитратных групп фтором составляет от 15 до 45\%.

Наблюдаемое различие в реакционной способности галоидов щелочных металлов объясняется степенью гидратации, зависящей от радиуса аниона нуклеофильного агента.

Взаимодействие НЦ с KSCN [43] представляет собой еще один пример нуклеофильного замещения нитратной группы на ион $\mathrm{SCN}^{-}$с образованием родандезоксинитрата целлюлозы:

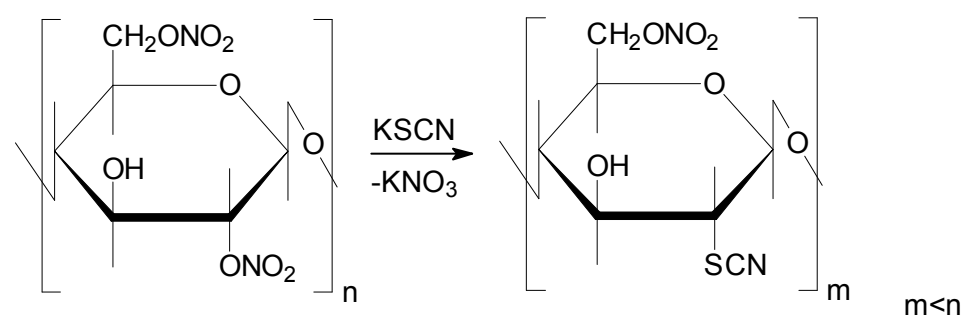

В гомогенной среде ацетона или циклогексанона был получен продукт со С3 по родановым группам 0,66. В водной среде удалось резко повысить количество вводимых родановых групп - до 0,80 .

А.П. Крешковым и др. [44] исследовано взаимодействие эфиров ортокремневой кислоты - тетраметокси-, тетраэтокси- и тетрабутоксисилана с частично замещенным НЦ, растворенным в смешанном растворителе (например, ацетон : этилацетат : метиловый спирт $=1: 0,2: 2,5$ ). Реакция может протекать по механизму переэтерификации или алкоголиза целлюлозой тетраалкоксисилана:

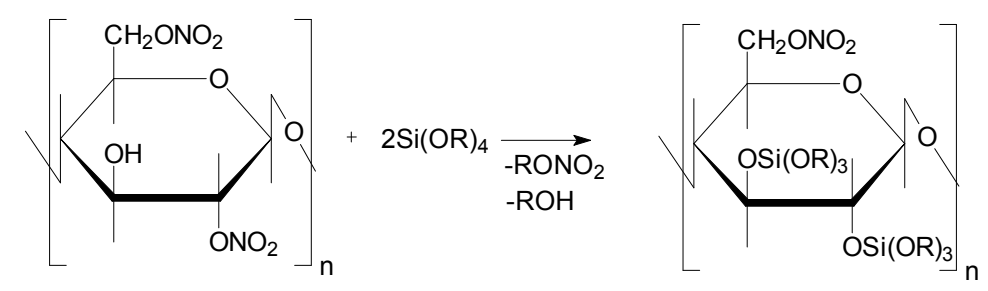

Авторы [44] считают, что более вероятен алкоголиз целлюлозой тетраалкоксисилана, так как при взаимодействии указанных реагентов выделяется спирт. Содержание кремния, введенного по этой реакции в молекулу целлюлозы, составляет 0,3-0,5\%. При взаимодействии НЦ с указанными алкоксисиланами, содержащими $0,01 \% \mathrm{SiCl}_{4}$, увеличивается содержание кремния с одновременным уменьшением содержания азота.

В патенте США $[45,39]$ описано взаимодействие НЦ с содержанием азота от 4,9 до 12,6\% с азидами натрия и лития. Взаимодействие осуществляли в среде ДМФА, ДМСО, ТГФ, этиленгликоля, этиленгликоль- 
моноэтилэфира при различных температурах и различном времени выдержки. Реакция шла по нитратным группам по механизму $\mathrm{S}_{\mathrm{N}}^{2}$, полученные полимеры имеют С3 на азидогруппу в диапазоне от 0,33 до 1,00.

Китайскими учеными [46] с целью уменьшения энергетических ограничений НЦ и улучшения его низкотемпературных механических свойств путем снижения температуры стеклования синтезирован азидо-замещенный в боковую цепь НЦ. Исходный НЦ подвергали химическому взаимодействию по свободным гидроксильным группам с изофрондиизоционатом, затем вводили в реакцию 2,2-бис-азидометил-1,3пропандиол.

Авторами $[47,48]$ была изучена реакция взаимодействия калиевых солей метил-, этил-, изопропил-, изооктилксантогеновых кислот с НЦ с различным содержанием нитратных групп (11,55 и 12,55\%) в среде ДМФА. Установлено, что при действии алкилксантогенатов калия на НЦ параллельно осуществляется три процесса: замещение нитратной группы алкилксантогенной, раскрытие цикла глюкопиранозы с присоединением к образовавшимся свободным связям молекулы алкилксантогеновой кислоты и омыление нитратных групп.

С.В. Фридландом с сотрудниками [49] изучено фосфорилирование НЦ белым фосфором в присутствии гидроксида калия. Гидроксид-ион позволяет расщепить Р-Р связь в атомах белого фосфора, генерируя фосфид-анионы. Предполагаемого замещения нитратных групп не произошло, а реакция прошла с разрывом $\beta$-1,4-глюкопиранозной связи НЦ.

В АлтГУ О.А. Панченко с сотрудниками [50] осуществлено модифицирование НЦ по свободным гидроксильным группам метакриловой кислотой в присутствии бензоилпероксида, а также муравьиной, уксусной и пропионовой кислотами в присутствии ангидрида трифторуксусной кислоты. Выбрана оптимальная продолжительность реакции, которая лежит в пределах 15-30 мин при температуре $30{ }^{\circ} \mathrm{C}$.

Joseph Park и Malcolm Gordon Stewart [51] провели реакции НЦ с содержанием азота 11,6-12,2\% с перфтороктановой кислотой в смеси ацетона и воды (95\%:5\%) при температуре $90{ }^{\circ} \mathrm{C}$ в течение 10 ч и гептафторбутирилхлоридом в толуоле с добавлением $\mathrm{NaOH}$ для поддержания $\mathrm{pH}=5-6$ при температуре $80{ }^{\circ} \mathrm{C}$ в течение 5 ч. Полученные продукты содержали до $1 \%$ фтора.

Авторами [52] изучена реакция НЦ со степенью замещения по нитратным группам 1,15 с хлоридом 3 -хлор-3-гидроксипропилтриметиламмония. Получен продукт со С3 по нитратным группам 1,03, по $\mathrm{NR}_{4}^{+}-$ 0,38, на котором исследована адсорбция креатинина.

\section{Реакции с электрофилами}

Амфотерный характер молекулы НЦ обусловливает его взаимодействие с электрофилами. Электрофильное замещение заключается в замещении гидроксильных групп на группировки, обладающие пониженной электронной плотностью $\left(E^{+}\right)$. Использование этой реакции представляет большой интерес, в частности при синтезе металлорганических соединений [53]:

Наличие в нитратной группе центров с ярко выраженными нуклео-

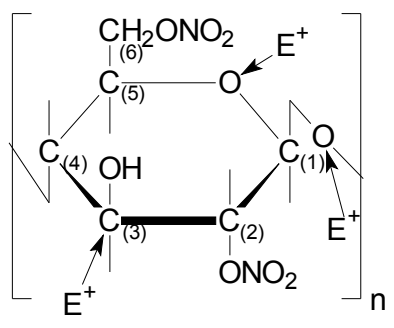
фильными и электрофильными свойствами также позволяет высказать предположение о возможности участия НЦ в реакциях с некоторыми диполярными реагентами по типу циклического электронного переноса [54].

При проверке данного предположения в работе [54] было найдено, что бромаль и хлораль реагируют с НЦ. Причем в определенных условиях замещаются количественно как первичные, так и вторичные нитратные группы. Конечными продуктами реакции являются эфиры целлюлозы с трибром- и трихлоруксусной кислотами. Авторами предложена следующая схема протекания реакции, приводящая к синтезу конечных продуктов, где $\mathrm{R}$ - элементарное звено $\mathrm{HЦ,} \mathrm{X}-\mathrm{Cl}, \mathrm{Br}$ :

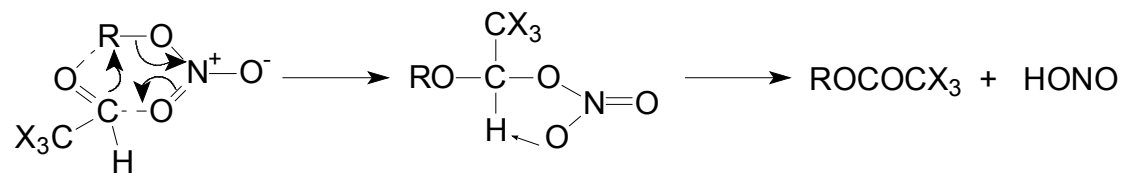

Нуклеофильность кислорода в хлорале, бромале сильно ослаблена индуктивным эффектом, поэтому атака осуществляется одним из атомов кислорода нитратной группы по электрофильному атому углерода 
альдегидной группы. Эта стадия является ведущей при трансформации переходного состояния. Каталитическое действие основано на увеличении электрофильности атома углерода альдегида и облегчении протекания реакции по схеме:

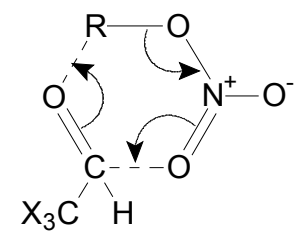

Источником $\mathrm{H}^{+}$могут служить образующиеся в процессе реакции азотистая кислота и присутствующие или образующиеся в условиях проведения синтеза из хлораля и бромаля следы галоидоводородов. Большей скоростью образования соединений кислотного характера из бромаля в условиях реакции объясняется более высокая скорость его взаимодействия по сравнению с хлоралем. Кроме того, неустойчивый к действию кислот НЦ крайне легко отщепляет нитратные группы при проведении реакции с бромалем в растворе уксусной, муравьиной кислот. Конечный продукт после этого практически не содержит азота и брома, что, возможно, является следствием преимущественного протекания гидролитического распада высокореакционноспособного продукта по общей схеме:

$$
\mathrm{CBr}_{3}-\mathrm{HC}_{\mathrm{ONO}_{2}}^{-\mathrm{OR}} \stackrel{\mathrm{H}^{+}}{\mathrm{H}_{2} \mathrm{O}} \mathrm{CBr}_{3} \mathrm{CHO}+\mathrm{ROH}+\mathrm{HNO}_{2}
$$

В $[55,48]$ рассмотрено взаимодействие ацетилнитрата целлюлозы с соединениями, содержащими полярные кратные связи: ацетонитрилом и малононитрилом. Показано, что реакция может протекать по механизму согласованного переноса электронов в четырех- или шестичленном циклах, причем строение получающихся продуктов будет различно:

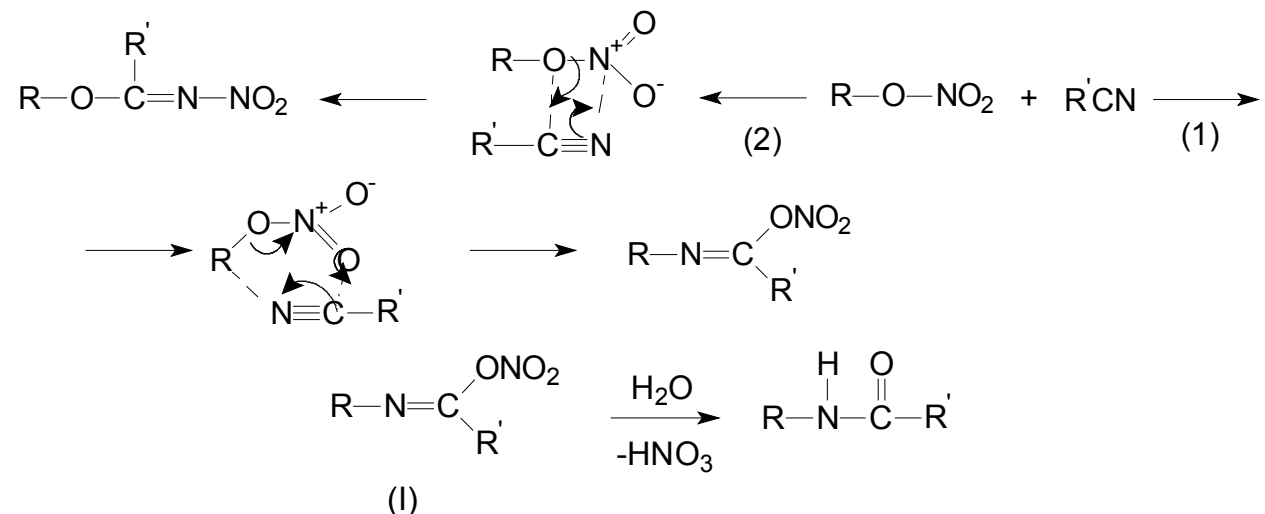

где $\mathrm{R}-\mathrm{C}\left(\mathrm{C}_{6} \mathrm{H}_{5}\right)_{3} ; \mathrm{R}^{\prime}-\mathrm{CH}_{3}$.

Малононитрил значительно более реакционноспособен, чем ацетонитрил. Это обусловлено большей электрофильностью $\mathrm{CN}$-групп малононитрила, а также, по-видимому, дополнительной возможностью для стабилизации переходного состояния в результате невалентного взаимодействия $\pi$-орбиталей, не участвующих в реакции кратных связей нитрильной и нитратной групп [55].

НЦ вступает во взаимодействие с диоксидом серы в присутствии электрофильных катализаторов. Для синтеза используется не содержащий ОН-групп ацетилнитрат целлюлозы (АНЦ). Реакция проводится в течение четырех суток в присутствии эфирата $\mathrm{BF}_{3}$ при $15-20{ }^{\circ} \mathrm{C}$ в жидком $\mathrm{SO}_{2}$ [56]. В соответствии с ранее высказанным предположением о возможности реализации для реакций нитроэфиров с соединениями, содержащими полярные кратные связи, механизма циклического переноса электронов, предлагается следующая схема протекания реакции [54], конечным продуктом которой является нитрозилсульфат целлюлозы: 


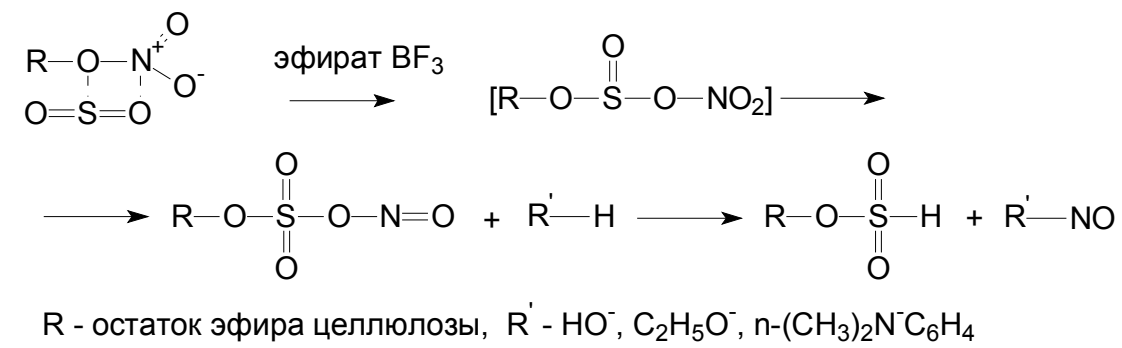

Рассмотренная выше способность бромаля и хлораля, ацетонитрила и малононитрила, двуокиси серы к взаимодействию с НЦ свидетельствует о возможности участия в реакции и других органических соединений, обладающих значительно меньшей, чем минеральные кислоты, электрофильностью. Известны исследования в этом направлении и изучены реакции хлорангидридов уксусной, трихлоруксусной и бензойной кислот с НЦ в присутствии каталитических количеств $\mathrm{BF}{ }_{3} \cdot \mathrm{O}\left(\mathrm{C}_{2} \mathrm{H}_{5}\right)_{2}$ [57]. Чтобы исключить возможность протекания реакции между гидроксильными группами НЦ и хлорангидридами кислот, для синтеза использовали не содержащие свободных гидроксильных групп ацетатнитрат целлюлозы и тринитрат целлюлозы. Установлено, что хлорангидриды карбоновых кислот взаимодействуют с НЦ с преимущественным замещением нитратной группы на ацильный остаток:

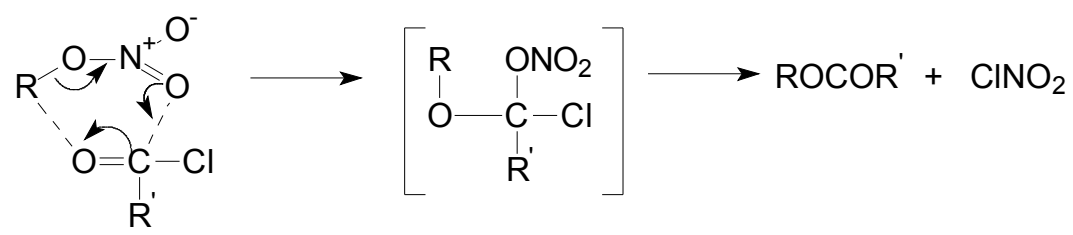

В продолжение высказанного ранее положения о возможности взаимодействия нитроэфирных групп с кратными связями веществ электрофильного характера в работе [58] с целью получения производных сульфоэфиров целлюлозы провели исследование реакции тринитрата целлюлозы и ацетилнитрата целлюлозы с хлористым сульфурилом, хлористым тионилом, диметилсульфатом и этиловым эфиром п-толуолсульфокислоты. Синтез осуществлялся в ампулах в присутствии $\mathrm{BF}_{3} \cdot \mathrm{O}\left(\mathrm{C}_{2} \mathrm{H}_{5}\right)_{2}$, в отсутствие которого реакция не идет.

Результаты анализов показывают, что все три компонента участвуют в элементарном акте реакции. В общем виде схему реакции НЦ с тионилхлоридом можно представить:

$$
\mathrm{R}-\mathrm{ONO}_{2}+\mathrm{SOCl}_{2} \stackrel{\mathrm{BF}_{3} \mathrm{O}\left(\mathrm{C}_{2} \mathrm{H}_{5}\right)_{2}}{\longrightarrow} \mathrm{R}-\mathrm{O}-\mathrm{SOCl}+\mathrm{CINO}_{2}
$$

Аналогичная реакция проведена [59] с тионилхлоридом в ДМФА. ДМФА образует с тионилхлоридом диметилформамидиний хлорид, который является активным катализатором реакции хлорирования. Продукты реакции содержат хлор и не имеют в составе серы.

Хлорнитрат целлюлозы получен при взаимодействии НЦ с хлоридом фосфора (V) в гетерогенной среде кипящего бензола [60], использование в качестве растворителя пиридина не привело к желаемому результату. Наряду с хлорированием происходит образование кратных и межмолекулярных связей.

В отечественной и зарубежной литературе существуют данные о способах получения фосфорсодержащих НЦ. Сотрудниками Института органической химии АН КиргССР в патенте [61] для этих целей был использован хлорангидрид фосфорной кислоты. Реакцию проводили в среде гексана, получили хорошо растворимый в ацетоне, этилацетате продукт с содержанием фосфора $0,13 \%$, азота - 12,32. Изобретение позволило снизить горючесть НЦ при сохранении С3 по азотнокислым группам.

По патентным данным [62] модификацию НЦ с содержанием азота 10-12,5\% проводили по свободным ОН-группам хлорангидридом диалкилфосфорной и диалкилфосфиновой кислот общей формулы $(\mathrm{RO})_{2} \mathrm{P}(\mathrm{O}) \mathrm{Cl}$ и $(\mathrm{R})_{2} \mathrm{P}(\mathrm{O}) \mathrm{Cl}(\mathrm{R}$ - различные и одинаковые алкильные или арильные радикалы). Модифицированный полимер содержал около $2 \% \mathrm{P}$, сохранил исходное содержание азота, приобрел устойчивость 
к горению, был растворим в большинстве растворителей, применяемых для получения лаков. В качестве растворителя использовали пиридин или смесь пиридин : диоксан.

Описанные выше способы [59-62] модификации НЦ позволяют вводить либо фосфор, либо галоид. С целью введения одновременно и фосфора, и хлора в патенте [63] предлагается в качестве органического реагента применять 2,2-дихлорвинилдиметилфосфат. Содержание фосфора и хлора в модифицированном НЦ может быть различным: хлора 5-13\%, фосфора 4-9\%. НЦ (N 11,8\%) в среде органического растворителя или без растворителя обрабатывают 2,2-дихлорвинилдиметилфосфатом при $100{ }^{\circ} \mathrm{C}$ в присутствии или отсутствии хлораля или бромаля.

Сотрудниками КГТУ А.В. Косточко и др. [64] получены ацетонитраты целлюлозы. НЦ из пироксилиновых порохов подвергали переэтерификации ацетилирующей смесью уксусный ангидрид : хлористый метилен : катализатор в массовом соотношении 30-60 : 53-132 : 0,18-2,0. В качестве катализатора в предложенном способе используют минеральные кислоты (серная, хлорная, фосфорная), вводимые в реакцию в количествах от 0,7 до 20 массовых частей от содержания НЦ.

Сотрудниками СамГТУ [65-67] изучены реакции взаимодействия НЦ из пироксилиновых порохов с малеиновым, фталевым ангидридами и олеатом натрия. Максимальные С3 на малеинатные, фталатные и олеатные группы были получены при проведении реакции в этилацетате в присутствии хлорной кислоты и составили 0,51-0,59. С3 нитратных групп в полученных продуктах снижается незначительно, если у исходного НЦ она имела значение 2,58, то у конечных продуктов составила 1,99-2,49.

В Германии Hüttermann Carsten и др. получены [68] анионные производные НЦ путем этерификации ОН-групп НЦ с содержанием азота 10,7-12,3\% ангидридами дикарбоновых кислот: янтарным, малеиновым, фталевым, итаконовым (метиленянтарным), глутаровым и додеценилянтарным, в среде уксусной кислоты при повышенной температуре (более $80{ }^{\circ} \mathrm{C}$ ). Полученные производные со С3 по дикарбоновой кислоте 0,01-0,25 нейтрализуют органическим амином или $\mathrm{NH}_{4} \mathrm{OH}$ и диспергируют в воде. Дисперсии анионных НЦ применяют как сокомпонент в алкидных, акрилатных или полиуретановых дисперсиях.

В развитие указанных выше исследований Е.А. Уткиной [69] с целью модификации свойств НЦ изучено взаимодействие их с ангидридами фталевой, масляной, янтарной кислот. Синтез химически модифицированных НЦ отличается проведением реакции в условиях более низких температур в среде ДМФА в присутствии гидрокарбоната натрия. Фталевый ангидрид проявил наименьшую реакционную активность. Масляный ангидрид, характеризующийся более длинным алкильным радикалом, менее активен по сравнению с янтарным.

В АлтГУ [70] О.А. Панченко с сотрудниками изучено влияние условий проведения реакций при взаимодействии 2,3-динитрата целлюлозы с пропионовым ангидридом и ангидридами дикарбоновых кислот: фталевым, малеиновым, янтарным. Модифицирование НЦ происходит по свободной гидроксильной группе у шестого атома углерода. Выбрана оптимальная продолжительность реакции, которая лежит в пределах 15-30 мин при температуре $30{ }^{\circ} \mathrm{C}$.

\section{Реакции НЦ по радикальному механизму}

Механизм радикального присоединения заключается в образовании в элементарном звене макромолекулы свободных радикалов путем разрыва в определенных условиях под действием инициатора прививки $G I$ связей $-\mathrm{NO}_{2}$ и ОН-групп и присоединения к ним различных соединений [2]:

Химическое строение НЦ, в частности наличие в ней реакционноспособных $-\mathrm{NO}_{2}$ и ОН-групп, которые могут быть использованы для образования макрорадикалов, позволяет осуществлять синтез привитых сополимеров. Цепная полимеризация - один из наиболее широко применяемых методов синтеза высокомолекулярных соединений.

Прививка виниловых мономеров (метилметакрилат, метилакрилат) на НЦ в гетерогенных и гомогенных средах, инициированная ионами церия и пероксида бензоила и азобисизобутироннитрила соответственно, исследована индийскими учеными [71]. Авторы предлагают следующий механизм реакции:

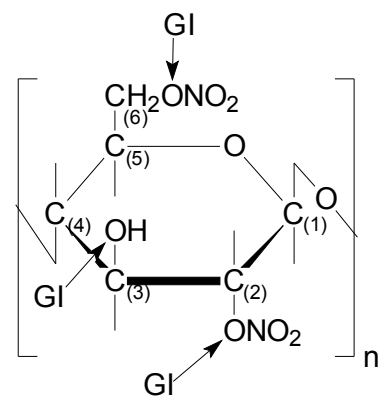




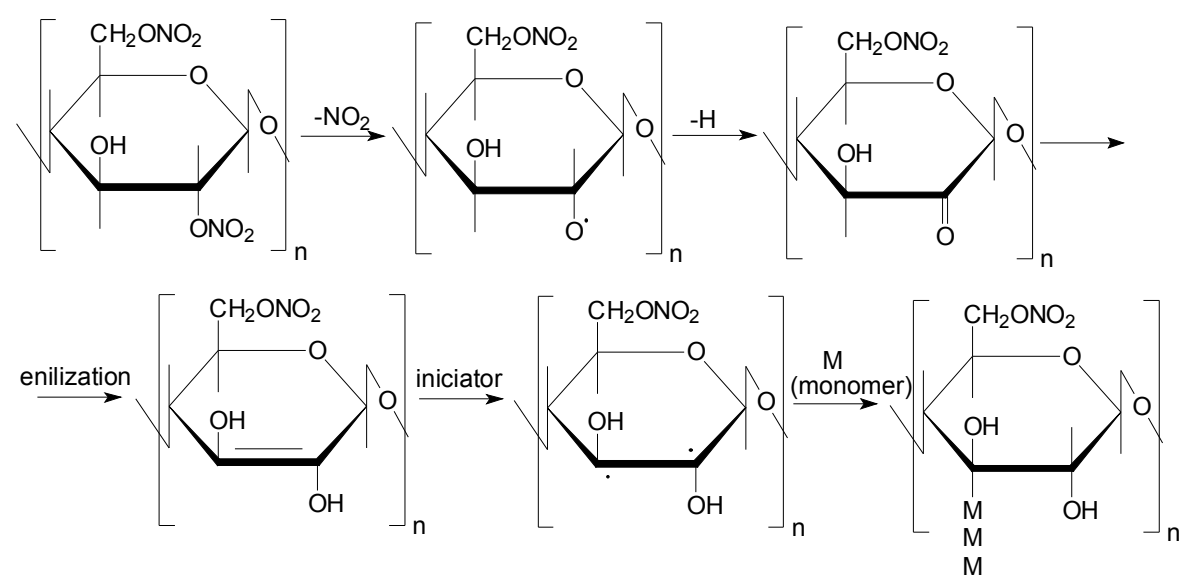

Японскими исследователями [72] получен окисленный с помощью $\mathrm{H}_{2} \mathrm{O}_{2}$ НЦ, предварительно модифицированный форполимером. Форполимер, в свою очередь, получен взаимодействием полиола (например, политетраметиленэфиргликоль) с эквимолярным количеством высшего органического диизоцианата (например, толуилендиизоцианат) и продлен диолом (например, 1,4-бутандиол).

Образование непредельных производных наблюдают при нагревании НЦ в запаянной ампуле в среде циклогексанона при $150{ }^{\circ} \mathrm{C}$ в течение 7 ч или нагревании при $130{ }^{\circ} \mathrm{C}$ в течение 30 ч [73, 74]. При такой обработке происходит почти полное отщепление нитратных групп и наряду с $\mathrm{C}=\mathrm{C}$-связями появляются $\mathrm{C}=\mathrm{O}, \mathrm{COOH}$ и ОН-группы.

Кроме того, результаты по анализу на азот и ИК-спектроскопии позволяют говорить об образовании C-N-связи и именно C-NO2-групп. Авторы [74] предполагают следующий механизм процесса:

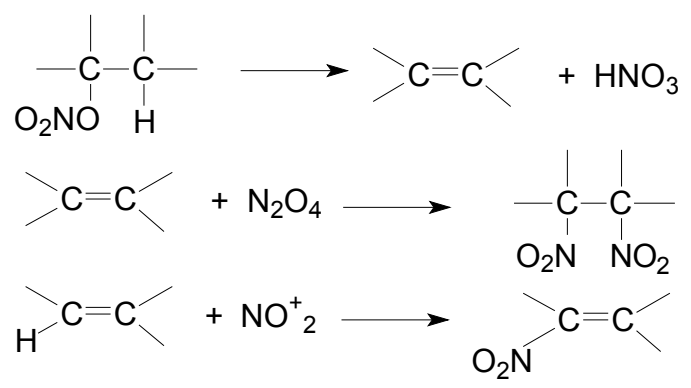

Образование оксидов азота обусловлено высокой температурой реакции. Появление карбонильных и карбоксильных групп объяснено возможным окислением оксидами азота.

Обзор литературы свидетельствует о том, что НЦ при взаимодействии с веществами, обладающими основными свойствами, претерпевают разнообразные химические превращения, вплоть до полного их разрушения с образованием простейших соединений, позволяя получать целый спектр как модифицированных НЦ, так и различных новых производных целлюлозы, не содержащих нитроэфирных групп. Кроме того, среди многочисленных реакций НЦ в присутствии агентов основного характера немало таких, которые идут с обращением конфигурации (вальденовское обращение) у вторичных углеродных атомов и, следовательно, приводят к образованию производных полисахаридов. Вальденовское обращение наблюдается во всех случаях нуклеофильного замещения, протекающего по бимолекулярному механизму $S_{N}^{2}$. Взаимодействие веществ по данному механизму зависит от основности реагента и подвижности уходящей группы субстрата. Бимолекулярное нуклеофильное замещение протекает в одну стадию, при этом атака нуклеофила и отщепление уходящей группы происходит одновременно.

С электрофилами НЦ в основном реагируют по пути этерификации гидроксильных групп и реакции катализируются $\mathrm{H}^{+}$. С некоторыми электрофилами, содержащими кратные связи, НЦ взаимодействуют по механизму циклического электронного переноса.

Таким образом, большинство известных к настоящему времени химических взаимодействий нитратных групп азотнокислых эфиров целлюлозы можно условно разделить на реакции гетеролиза сложноэфирной связи, в результате чего регенерируется исходная гидроксильная группа либо образуются ангид- 
ро- или окисленные формы, на реакции нуклеофильного и электрофильного замещения нитратных групп, обусловленные сильной поляризацией имеющихся эфирных связей, с появлением новой эфирной связи, дезокси- и других производных, а также реакции термолиза, в ходе которых происходит разрыв пиранозного цикла и образование низкомолекулярных соединений (рис. 1-3).

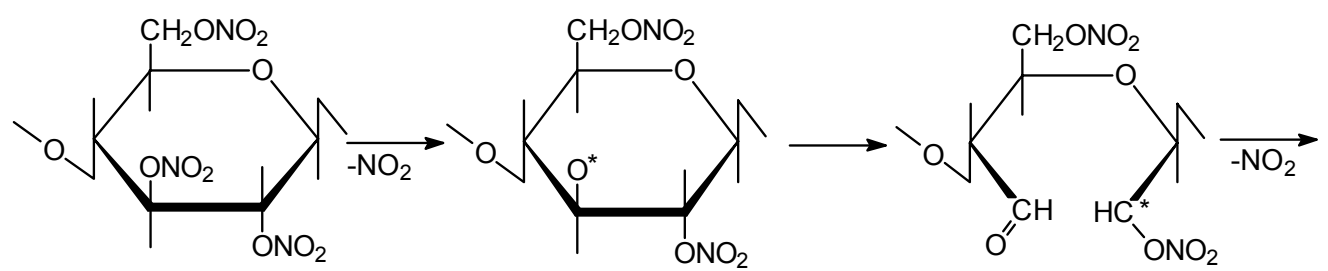

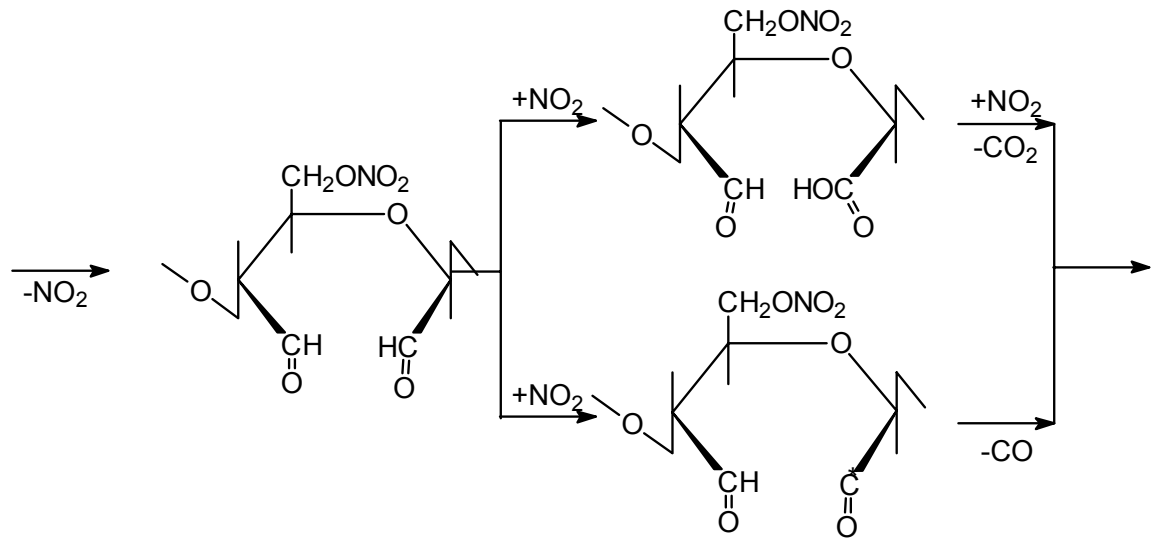

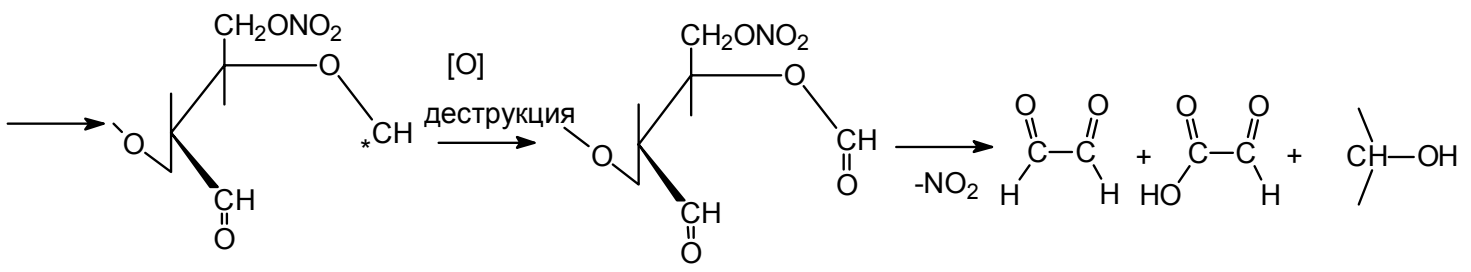

Рис. 1. Вероятная схема термолиза НЦ
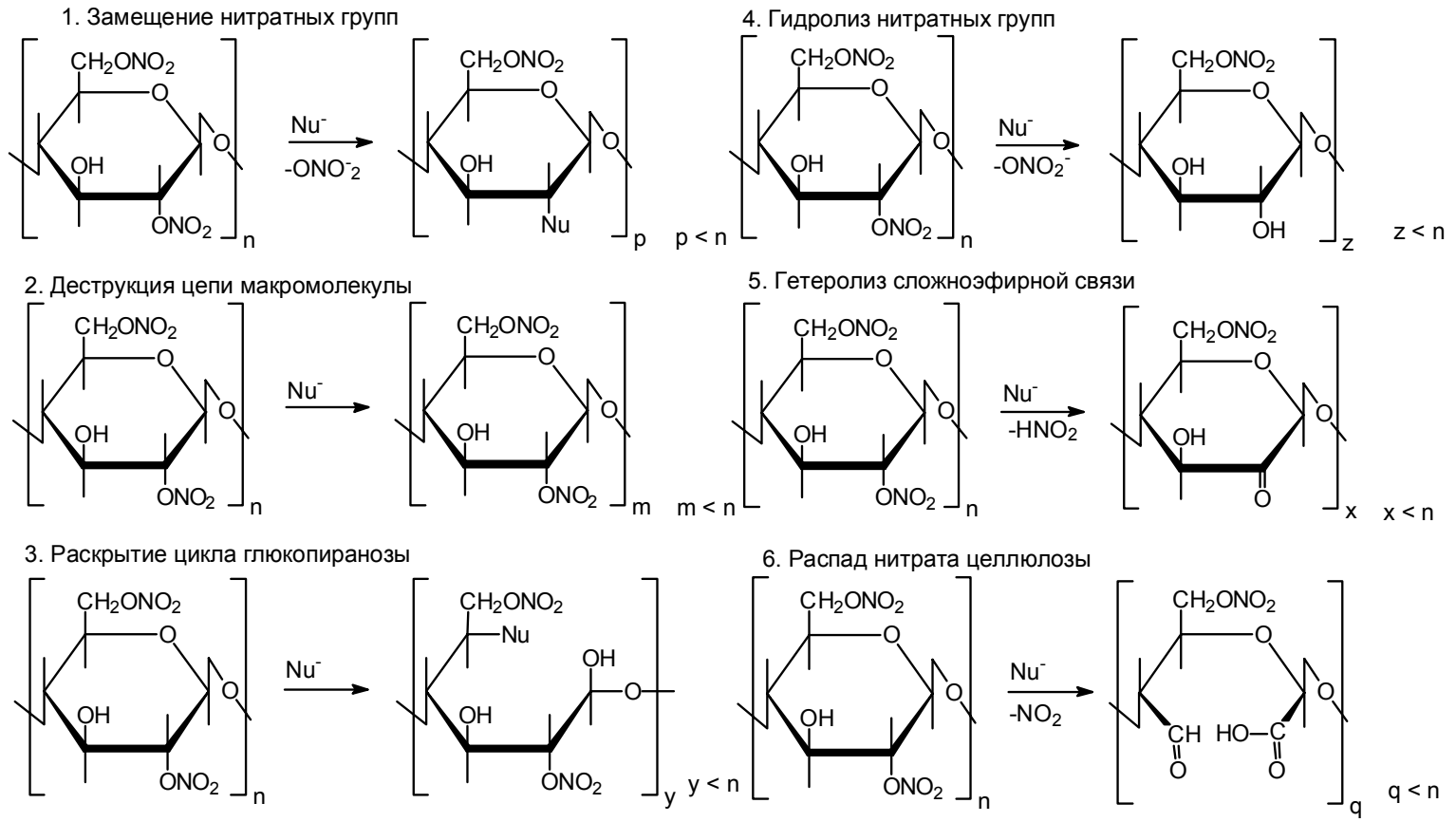

Рис. 2. Вероятные направления взаимодействия НЦ с нуклеофилами 

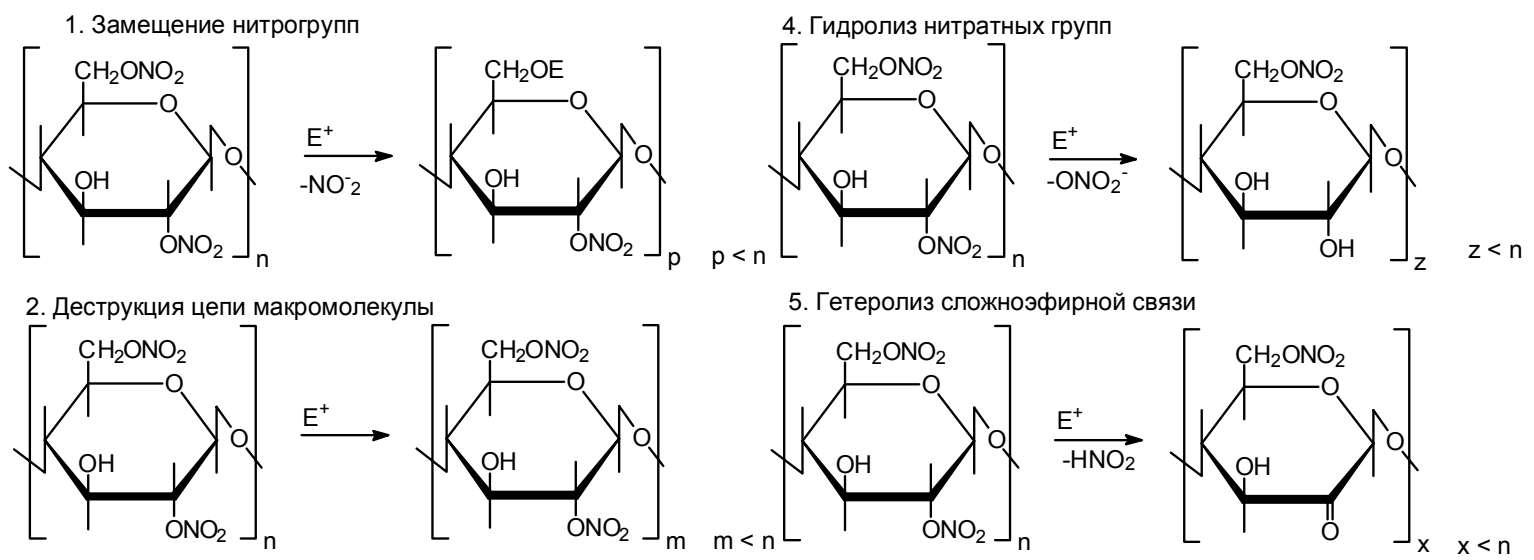

5. Гетеролиз сложноэфирной связи

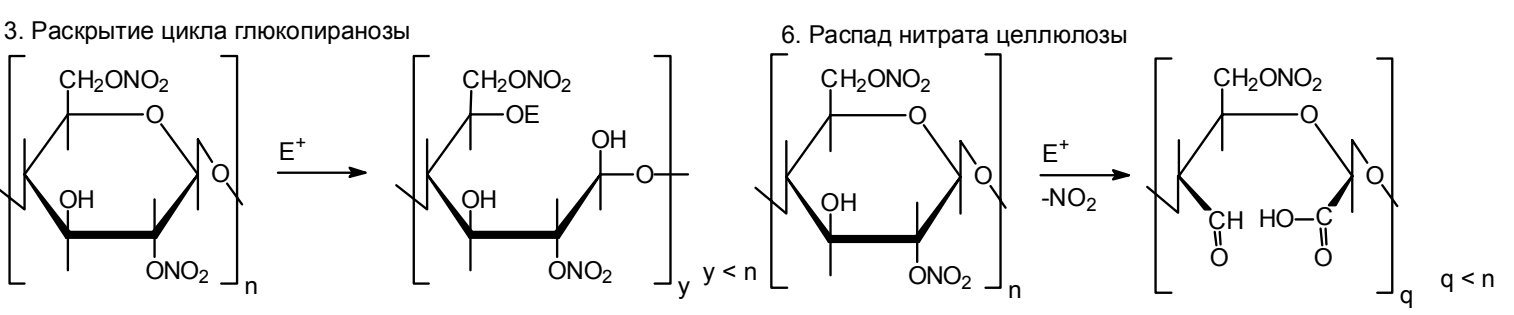

Рис. 3. Вероятные направления взаимодействия НЦ с электрофилами

\section{Список литературы}

1. Косточко А.В. Специальные полимеры и композиции : избранные статьи. Казань, 1999. 224 с.

2. Роговин 3.А., Гальбрайх Л.С. Химические превращения и модификация целлюлозы: изд. 2-е, перераб. и доп. M., 1979. 208 c.

3. Spurlin H.M. Homogeneity and properties of Nitrocellulose// Ind. Eng. Chem. 1938. Vol. 30. Pp. 538-542.

4. Wu T.K. Studies of reaction nitrocellulose // Amer. Chem. Soc. polym. prepr. 1979. Vol. 20. N 2. Pp. 409-412.

5. Wu T.K. Carbon-13 and proton nuclear magnetic resonance studies of cellulose nitrates // Macromolecules. 1980. Vol. 13. N 1. Pp. 74-79.

6. Clark O.T., Stephensen P.J., Heatley F. New properties cellulose nitrates // Polymer. 1981. N 8. Pp. 1112-1117.

7. Роговин 3.А. Химические превращения и модификация целлюлозы. М., 1967. 198 с.

8. Кувшинова Е.М., Петров О.А., Гусева Л.Ж., Хелевина О.Г. Органическая химия. Реакции нуклеофильного замещения : учеб. пособие. Иваново, 2010. 56 с.

9. Касько Н.С., Кандауров В.П. Исследование межмолекулярного взаимодействия нитратов целлюлозы с нуклеофильными реагентами // Химия растительного сырья. 1997. № 1. С. 34-38.

10. Закощиков А.П. Нитроцеллюлоза. М., 1950. 258 с.

11. Farmer R.C. Preparation of pure $\mathrm{CO}_{2}$; velocity of decomposition of high explosive in a vacuum; trinitrophenylnitramine (tetryl), stability of benzoyl peroxide // J. Chem. Soc. 1920. Vol. 117. N 692. Pp. 806-818.

12. Loury T.M., Browning K.C., Farmery J.W. Synthesis and properties of nitrates ethers // J. Chem. Soc. 1920. N 691. Pp. 522-561.

13. Shuler E., Burger K., Seher M. Reactions of threenitrocellulose // J. analyt. chem. 1960. N 2. Pp. 81-86.

14. Baker J.W., Easty D.M. Hydrolytic decomposition of esters of nitric acid // J. Chem. Soc. 1952. Pp. 1193-1207.

15. Кумбс Р.Дж. Азотсодержащие соединения // Общая органическая химия. 1982. Т. 3. С. 446.

16. Boschan R., Merrow R.T., Van Dolah R.W. The chemistry of nitrate esters // Chem. Rew. 1955. N 3. Pp. 485-510.

17. Shefered D.M. The preparation and properties of some alkyl- $\beta$-D-glycopiranoside tetranitrates // J. Chem. Soc. 1953. Pp. $3635-3637$.

18. Oldham J.W.H., Bell D.J. The chemistry of nitrate cellulose // J. Chem. Soc. 1938. Pp. 323-325.

19. Rassow B., Dorr E. The reactions of nitrates esters // J. Pract. Chem. 1924. Vol. 216. Pp. 113-115.

20. Falconer E.L., Purves C.B. Assignment of structure to cellulose 3,6-dinitrate // J. Amer. Chem. Soc. 1957. Vol. 79. Pp. 5308-5310.

21. Merrow R.T., Cristol S.J., Van Dolah R.W. Reaction of n-butyl nitrate with alkaline hydrosulfides // J. Amer. Chem. Soc. 1953. Vol. 75. Pp. 4259-4265.

22. Honeyman J., Morgan J.W.W. Sugar Nitrates // J. Amer. Chem. Soc. 1955. Vol. 79. Pp. 3660-3674.

23. Деревицкая В.А., Федорова В.Ф., Роговин 3.А. Изучение реакционной способности нитратных групп тринитроцеллюлозы // Научно-исследовательские труды МТИ. 1956. Т.18. С. 82-86. 
24. Патент № 2201912 (РФ). Эмульсионный способ переработки порохов / Н.С. Латфуллин, А.А. Староверов, Д.В. Хамитова, Н.М. Ляпин, Т.А. Енейкина / 2003.

25. Scherer P.C., Saul G.A. Reaction between cellulose nitrate and $\mathrm{Na}$ acetylide in liquid $\mathrm{NH}_{3} / /$ Rayon Textile Monthly. 1974. Vol. 28. Pp. 474-475.

26. Scherer P.C., Feild J. Preparation of a cellulose amine // Rayon Textile Monthly. 1941. Vol. 22. Pp. 607-605.

27. Чайкина Е.А., Гальбрайх Л.С., Роговин 3.А. Исследование сравнительной реакционной способности тозиловых и азотнокислых эфиров целлюлозы в реакциях нуклеофильного замещения с аминобензойными кислотами // Высокомолекулярные соединения. 1967. Сер. Б. Т. 9. С. 151-155.

28. Ikeda Isao, Nobuhito Hirata, Saburo Komori, Mituo Okahara. Preparation and surface activity of 1,1,1trimethylamine-2-(alkylcarbamoyl)imides // Nippon Kagaku Kaishi. 1975. Pp. 135-138.

29. Степанова Н.В., Нургатин В.В., Фридланд С.В. Взаимодействие нитратов целлюлозы с анилином // Тезисы докладов Всероссийской конференции по вопросам окружающей среды на урбанизированных территориях. Пермь, 1995. С. 37.

30. Verhoeven M.L.P.M. Cellulose nitrate as a biocompatible support to immobilize proteins and ligands for hemoperfusion: proefshrift doctor a an de Technische Universiteit Eindhoven. Helmond, 1988. 135 p.

31. Данилов С.Н., Мирлас А.И. О снижении вязкости нитроцеллюлозы // Журнал общей химии. 1934. Т. 4. C. $817-828$.

32. Hayward J., Purves C.B. The action of hydroxylamine on methyl alpha- and beta-D-glycopiranoside tetranitrate in pyridine // Canad. J. Chem. 1954. Vol. 32. Pp. 19-30.

33. Segall G.H., Purves C.B. The chemistry and properties of D-glycopiranoside tetranitrate // Canad. J. Chem. 1952. Vol. 30. Pp. 860-871.

34. Романова С.М., Мухетдинова А.М., Фридланд С.В. Химическая модификация азотнокислых эфиров целлюлозы производными гидразина // Вестник КТУ. 2010. № 9. С. 124-130.

35. Патент № 2157817 (РФ). Сложные смешанные азотнокислые эфиры целлюлозы с капролактамными группами и способ их получения / Н.П. Логинов, С.Н. Логинова / 2000.

36. Honeyman J., Morgan J.W.W. The action of sugar nitrates // Advances in Carbohyd. Chem. N-Y. 1957. Vol. 12. Pp. 117-135.

37. Murray G.E. Purves C.B. The preparation of fibrous iodo-cellulose nitrates and the probable distributions of nitrate groups in partly nitrated cellulose // J. Amer. Chem. Soc. 1940. Vol. 62. Pp. 3194-3197.

38. Слеткина Л.С., Поляков А.И., Роговин 3.А. Исследование некоторых закономерностей реакций нуклеофильного замещения различных эфиров целлюлозы с солями галоидводородных кислот // Высокомолекулярные соединения. 1965. Т. 7. С. 199-204.

39. Gilbert E.E. The reaction of cellulose nitrate with several nucleophiles // Journal of Energetic Materials. 1985 . N 3-4. Pp. 319-333.

40. Achwal W.B. New method of preparation 5,6-cellulosen from nitrates cellulose // Indian J. Technol. 1968. Vol. 6. Pp. 235-238.

41. Achwal W.B., Deshpande S.D. Preparation of 5, 6-Celluloseen From Cellulose Nitrate of Low Degree of Substitution // Current Science (India). 1969. Vol. 38. N 18. Pp. 425-427.

42. А. с. 254767 (СССР). Способ получения фторсодержащих полимеров / В.П. Безсолицен, Б.Н. Горбунов, С.С. Радченко, А.П. Хардин, А.Е. Овчинникова / 1970.

43. Лишевская М.О., Вирник А.Д., Роговин 3.А. Химические свойства и модификация полимеров // Высокомолекулярные соединения. 1964. № 2. С. 243-247.

44. Крешков А.П., Гурецкий И.Я., Андреев П.А. Взаимодействие некоторых кремнийорганических соединений с нитратами целлюлозы // Журнал общей химии. 1958. Т. 28. С. 187-193.

45. Patent 4568399 (USA). Propellant compositions / Everett E. Gilbert / 1986.

46. Yang Fei-fei, Shao Zi-qiang, Wang Fei-jun, Wang Wen-jun, Zhang You-de, Wang Hui-qing. Synthesis and properties of azido-sidechain branched NC // Chinese Journal of Energetic Materials. 2011. N 4. Pp. 391-395.

47. Романова С.М., Нургатин В.В., Фридланд С.В. Исследование реакционной способности нитратов целлюлозы в реакциях с производными ксантогеновых кислот // Изв. вузов. Химия и хим. технология. 2003. Т. 46, вып. 8. C. $134-138$.

48. Романова С.М., Мадякина А.М., Фридланд С.В. Возможные пути протекания реакций взаимодействия нитратов целлюлозы с солями ксантогеновых кислот // Вестник КТУ. 2011. №2. С. 147-154.

49. Фридланд С.В., Макарова Н.А., Фридланд Н.С. Фосфорилирование нитратов целлюлозы белым фосфором // Журнал органической химии. 2000. Т. 70, вып. 6. С. 1052.

50. Панченко О.А., Шушакова М.В., Карелин А.С. Получение смешанных азотнокислых эфиров из динитратов целлюлозы и карбоновых кислот // Новые достижения в химии и химической технологии растительного сырья: материалы IV Всероссийской конференции. Барнаул, 2009. Т. 1. С. 103-104.

51. Patent 1120373 (GB). Film-forming cellulose compounds / J. Park, M.G. Stewart / 1968.

52. Wang Shao-Min, Yu Jiu-Gao. Synthesis and Application of the Quaternary Ammonium Cellulose Nitrate // Chin. J. Appl. Chem. 2004. N 5. Pp. 493-497.

53. Роговин 3.А., Шорыгина Н.Н. Химия целлюлозы и ее спутников. М., 1953. 680 с.

54. Поляков А.И., Спиридонова Л.И. Взаимодействие нитратов целлюлозы с хлоралем и бромалем // Известия АН ССР. Серия химическая. 1969. № 7. С. 1562-1567. 
55. Shererr P.C., Feild I. Aminimide - containing molecules and materials as molecular recognition agent // New-York. 1941. Pp. 607.

56. Ermo K. Papezi Japin // New-York. 1958. Pp. 340.

57. Поляков А.И., Смагин В.В. Взаимодействие нитрата целлюлозы с хлорангидридами карбоновых кислот // ВMC. 1972. Т. XIV. № 6. С. 1278-1282.

58. Спиридонова Л.И., Ланина Н.А., Горохова В.Г., Поляков А.И. Взаимодействие нитратов целлюлозы с некоторыми кислородосодержащими производными серы // Журнал органической химии. 1974. Т. 10. № 2. С. 131-135.

59. Романова С.М., Мадякина А.М., Фридланд С.В. Синтез хлорнитратов целлюлозы // Труды XV Международного симпозиума «Энергоресурсоэффективность и энергосбережение в Республике Татарстан». Казань, 2015. C. $322-323$.

60. Романова С.М., Мадякина А.М. Взаимодействие нитратов целлюлозы с хлоридом фосфора (V) // Журнал экологии и промышленной безопасности. 2014. № 1-2. С. 53-55.

61. А.с. 1407929 (СССР). Способ модификации нитратов целлюлозы / Р.И. Сарыбаева, М.С. Джумабаева / 1988.

62. Patent 3808199 (USA). Organophosphorus modified cellulose nitrate / Lin Kuang-Farn, Rheineck Alfred E. / 1974.

63. Патент № 255237 (СССР). Способ модификации нитратов целлюлоз / М.Ф. Шостаковский, А.И. Поляков, Л.В. Васильева, Л.А. Ильина, Л.Н. Спиридонова / 1969.

64. Патент № 2092493 (РФ). Способ получения сложного ацетонитрата целлюлозы / А.В. Косточко, И.Н. Краснов, А.И. Петров, В.Ф. Васильев, Б.С. Колесов, В.В. Ильин, З.М. Сафина / 1997.

65. Логинов Н.П. Разработка технологии модификации нитроцеллюлозы из порохов и технологии производства из нее пластмасс промышленного и хозяйственного назначения // Аннотации научно-технических проектов 2 Всеросс. науч.-практ. конф. «Высшая школа России: конверсия и приоритетные технологии». М., 1996. С. 608-609.

66. Патент № 2170235 (РФ). Сложные смешанные азотнокислые эфиры целлюлозы с фталатными группами в качестве полимерной основы клеев, лаков, красок, покрытий твердых ракетных топлив и способ их получения / Н.П. Логинов, В.С. Клеменко, Е.В. Камнева, Ю.В. Воробьева / 2001.

67. Патент № 2137778 (РФ). Сложные смешанные азотнокислые эфиры целлюлозы с малеинатными группами в качестве высокомолекулярной основы клеевых, лакокрасочных полимерных материалов и способ их получения / Н.П. Логинов, В.С. Клеменко, Е.В. Камнева, Ю.В. Воробьева / 1999.

68. Patent 7071326 B2 (US). Anionic cellulose nitrate derivatives and aqueous dispersions thereof / Hüttermann Carsten, Wagner Thomas, Nachtkamp Klaus / 2006.

69. Уткина Е.И., Романова С.М., Шипина О.Т. Исследование реакции взаимодействия нитратов целлюлозы с имидами карбоновых кислот // Международная конференция по химической технологии (посвящается 100летию со дня рождения академика Н.М. Жаворонкова). М., 2007. С. 177-180.

70. Панченко О.А., Шушакова М.В., Карелин А.С. Модификация нитратов целлюлозы ангидридами карбоновых кислот / Новые достижения в химии и химической технологии растительного сырья: материалы IV Bcepocсийской конференции. Барнаул, 2009. Т. 1. С. 104-106.

71. Srinivasan K. S. V., Hon D. N.-S., Santappa M. Graft Copolymerization of Lignocellulosic Fibers // ACS Symposium series «Graft Copolymerization of Lignocellulosic Fibers». American Chemical Society. Washington DC, 1982. Pp. 155-178.

72. Patent H047318 A (JP). Nitrocellulose modified with oxidized urethane and its preparation / Harada Munenori / 1992.

73. Козлова А.Ф., Снежко В.А., Хомыков К.П. Синтез непредельных производных целлюлозы и декстрана // Известия вузов. Химия и химическая технология. 1974. Т. 17. С. 1890-1891.

74. Козлова А.Ф., Комар В.П., Петрова Т.Н., Вирник А.Д. Химическая активность некоторых производных целлюлозы // Cell. C. and technol. 1976. Vol. 17. Pp. 3-16.

Поступило в редакцию 19 октября 2016 г.

После переработки 22 ноября 2016 г. 
Romanova S.M., Madyakina A.M., Sabirova D.I.*, Khuzeev M.V. CHEMICAL MODIFICATION OF CELLULOSE NITRATE (REVIEW)

Kazan National Research Technological University, ul. Karla Marksa, 68, Kazan', 420015 (Russia), e-mail:dinka-sab@mail.ru

Published data on the reactions of cellulose nitrate with different reagents occurring by the donor-acceptor, radical mechanisms were generalized and systematized. The schemes of probable ways of reactions with nucleophiles and electrophiles were presented. The features of the chemical structure of cellulose nitrate macromolecules cause the possibility of chemical reactions on different reaction centers of elementary unit: reactions of nitrate groups, reactions of the available free hydroxyls and reactions of glycoside bond, always leading to the destruction of the polymer. Review of scientific and patent literature on this subject indicates that action of various kinds of chemicals on cellulose nitrate, as well as light and heat, leads to three types of reaction occurring concurrently, and the reactivity of each of the centers is in direct dependence on the next environment in an elementary link, changing in the process.

Keywords: modification, cellulose nitrate, transesterification, reactivity.

\section{References}

1. Kostochko A.V. Spetsial'nye polimery i kompozitsii. Izbrannye stat'i. [Special polymers and compositions. Selected articles]. Kazan', 1999. 224 p. (in Russ.).

2. Rogovin Z.A., Gal'braikh L.S. Khimicheskie prevrashcheniia i modifikatsiia tselliulozy. [Chemical transformations and modification of cellulose]. Moscow, 1979. 208 p. (in Russ.).

3. Spurlin H.M. Ind. Eng. Chem., 1938, vol. 30, pp. 538-542.

4. Wu T.K. Amer. Chem. Soc. polym. prepr., 1979, vol. 20, no. 2, pp. 409-412.

5. Wu T.K. Macromolecules, 1980, vol. 13, no. 1, pp. 74-79.

6. Clark O.T., Stephensen P.J., Heatley F. Polymer, 1981, no. 8, pp. 1112-1117.

7. Rogovin Z.A. Khimicheskie prevrashcheniia i modifikatsiia tselliulozy. [Chemical transformations and modification of cellulose]. Moscow, 1967, 198 p. (in Russ.).

8. Kuvshinova E.M., Petrov O.A., Guseva L.Zh., Khelevina O.G. Organicheskaia khimiia. Reaktsii nukleofil'nogo zameshcheniia: ucheb. posobie. [Organic chemistry. Reactions of nucleophilic substitution: a study guide.]. Ivanovo, 2010, 56 p. (in Russ.).

9. Kas'ko N.S., Kandaurov V.P. Khimiia rastitel'nogo syr'ia, 1997, no. 1, pp. 34-38. (in Russ.).

10. Zakoshchikov A.P. Nitrotselliuloza. [Nitrocellulose]. Moscow, 1950, 258 p. (in Russ.).

11. Farmer R.C. J. Chem. Soc., 1920, vol. 117, no. 692, pp. 806-818.

12. Loury T.M., Browning K.C., Farmery J.W. J. Chem. Soc., 1920, no. 691, pp. 522-561.

13. Shuler E., Burger K., Seher M. J. Analyt. Chem., 1960, no. 2, pp. 81-86.

14. Baker J.W., Easty D.M. J. Chem. Soc., 1952, pp. 1193-1207.

15. Kumbs R.Dzh. Obshchaia organicheskaia khimiia, 1982, vol. 3, p. 446. (in Russ.).

16. Boschan R., Merrow R.T., Van Dolah R.W. Chem. Rew., 1955, no. 3, pp. 485-510.

17. Shefered D.M. J. Chem. Soc., 1953, pp. 3635-3637.

18. Oldham J.W.H., Bell D.J. J. Chem. Soc., 1938, pp. 323-325.

19. Rassow B., Dorr E. J. Pract. Chem., 1924, vol. 216, pp. 113-115.

20. Falconer E.L., Purves C.B. J. Amer. Chem. Soc., 1957, vol. 79, pp. 5308-5310.

21. Merrow R.T., Cristol S.J., Van Dolah R.W. J. Amer. Chem. Soc., 1953, vol. 75, pp. 4259-4265.

22. Honeyman J., Morgan J.W.W. J. Amer. Chem. Soc., 1955, vol. 79, pp. 3660-3674.

23. Derevitskaia V.A., Fedorova V.F., Rogovin Z.A. Nauchno-issledovatel'skie trudy MTI, 1956, vol.18, pp. 82-86. (in Russ.).

24. Patent 2201912 (RU). 2003. (in Russ.).

25. Scherer P.C., Saul G.A. Rayon Textile Monthly, 1974, vol. 28, pp. 474-475.

26. Scherer P.C., Feild J. Rayon Textile Monthly, 1941, vol. 22, pp. 607-605.

27. Chaikina E.A., Gal'braikh L.S., Rogovin Z.A. Vysokomolekuliarnye soedineniia, 1967, vol. 9, pp. 151-155. (in Russ.).

28. Ikeda Isao, Nobuhito Hirata, Saburo Komori, Mituo Okahara. Nippon Kagaku Kaishi, 1975, pp. 135-138.

29. Stepanova N.V., Nurgatin V.V., Fridland S.V. Tezisy dokladov Vserossiiskoi konferentsii po voprosam okruzhaiushchei sredy na urbanizirovannykh territoriiakh. [Theses of the reports of the All-Russian Conference on the Environment in Urban Territories]. Perm', 1995, p. 37. (in Russ.).

30. Verhoeven M.L.P.M. Cellulose nitrate as a biocompatible support to immobilize proteins and ligands for hemoperfusion: proefshrift doctor a an de Technische Universiteit Eindhoven. Helmond, 1988, 135 p.

31. Danilov S.N., Mirlas A.I. Zhurnal obshchei khimii, 1934, vol. 4, pp. 817-828. (in Russ.).

32. Hayward J., Purves C.B. Canad. J. Chem., 1954, vol. 32, pp. 19-30.

33. Segall G.H., Purves C.B. Canad. J. Chem., 1952, vol. 30, pp. 860-871.

34. Romanova S.M., Mukhetdinova A.M., Fridland S.V. Vestnik KTU, 2010, no. 9, pp. 124-130. (in Russ.).

35. Patent 2157817 (RU). 2000. (in Russ.).

36. Honeyman J., Morgan J.W.W. Advances in Carbohyd. Chem. N-Y., 1957, vol. 12, pp. 117-135.

37. Murray G.E. Purves C.B. J. Amer. Chem. Soc., 1940, vol. 62, pp. 3194-3197.

38. Sletkina L.S., Poliakov A.I., Rogovin Z.A. Vysokomolekuliarnye soedineniia, 1965, vol. 7, pp. 199-204. (in Russ.).

\footnotetext{
* Corresponding author.
} 
39. Gilbert E.E. Journal of Energetic Materials, 1985, no. 3-4, pp. 319-333.

40. Achwal W.B. Indian J. Technol., 1968, vol. 6, pp. 235-238.

41. Achwal W.B., Deshpande S.D. Current Science (India), 1969, vol. 38, no. 18, pp. 425-427.

42. Patent 254767 (SU). 1970. (in Russ.).

43. Lishevskaia M.O. Virnik A.D., Rogovin Z.A. Vysokomolekuliarnye soedineniia, 1964, pp. 243-247. (in Russ.).

44. Kreshkov A.P., Guretskii I.Ia., Andreev P.A. Zhurnal obshchei khimii, 1958, vol. 28, pp. 187-193. (in Russ.).

45. Patent 4568399 (USA). 1986.

46. Yang Fei-fei, Shao Zi-qiang, Wang Fei-jun, Wang Wen-jun, Zhang You-de, Wang Hui-qing. Chinese Journal of Energetic Materials, 2011, no. 4, pp. 391-395.

47. Romanova S.M., Nurgatin V.V., Fridland S.V. Izv. vuzov. Khimiia i khim. tekhnologiia, 2003, vol. 46, no. 8, pp. $134-138$. (in Russ.).

48. Romanova S.M., Madiakina A.M., Fridland S.V. Vestnik KTU, 2011, no. 2, pp. 147-154. (in Russ.).

49. Fridland S.V., Makarova N.A., Fridland N.S. Zhurnal organicheskoi khimii, 2000, vol. 70, no. 6, p. 1052. (in Russ.).

50. Panchenko O.A., Shushakova M.V., Karelin A.S. Novye dostizheniia v khimii i khimicheskoi tekhnologii rastitel'nogo syr'ia: materialy IV Vserossiiskoi konferentsii. [New achievements in chemistry and chemical technology of plant raw materials: materials of the IV All-Russian Conference]. Barnaul, 2009, vol. 1, pp. 103-104. (in Russ.).

51. Patent 1120373 (GB). 1968.

52. Wang Shao-Min, Yu Jiu-Gao. Chin. J. Appl. Chem., 2004, no. 5, pp. 493-497.

53. Rogovin Z.A., Shorygina N.N. Khimiia tselliulozy i ee sputnikov. [Chemistry of cellulose and its satellites]. Moscow, 1953, 680 p. (in Russ.).

54. Poliakov A.I., Spiridonova L.I. Izvestiia AN SSR, Seriia khimicheskaia, 1969, no. 7, pp. 1562-1567. (in Russ.).

55. Shererr P.C., Feild I. Aminimide - containing molecules and materials as molecular recognition agent // New-York. 1941. Pp. 607.

56. Ermo K. Papezi Japin // New-York. 1958. Pp. 340.

57. Poliakov A.I., Smagin V.V. VMS, 1972, vol. XIV, no. 6, pp. 1278-1282. (in Russ.).

58. Spiridonova L.I., Lanina N.A., Gorokhova V.G., Poliakov A.I. Zhurnal organicheskoi khimii, 1974, vol. 10, no. 2, pp. 131-135. (in Russ.).

59. Romanova S.M., Madiakina A.M., Fridland S.V. Trudy XV Mezhdunarodno-go simpoziuma «Energoresursoeffektivnost $i$ energosberezhenie $v$ Respublike Tatarstan». [Proceedings of the 15th International Symposium "Energy Resource Efficiency and Energy Saving in the Republic of Tatarstan"]. Kazan', 2015, pp. 322-323. (in Russ.).

60. Romanova S.M., Madiakina A.M. Zhurnal ekologii i promyshlennoi bezopasnosti, 2014, no. 1-2, pp. 53-55. (in Russ.).

61. Patent 1407929 (SU). 1988. (in Russ.).

62. Patent 3808199 (US). 1974.

63. Patent 255237 (SU). 1969. (in Russ.).

64. Patent 2092493 (RU). 1997. (in Russ.).

65. Loginov N.P. Annotatsii nauchno-tekhnicheskikh proektov 2 Vserosc. nauch.-prakt. konf. "Vyssh. shkola Rossii: konversiia i prioritetnye tekhnologii». [Annotations of scientific and technical projects of the 2 nd All-Russian Scientific and Practical Conference "Higher School of Russia: Conversion and Priority Technologies"]. Moscow, 1996, pp. 608-609. (in Russ.).

66. Patent 2170235 (RU). 2001. (in Russ.).

67. Patent 2137778 (RU). 1999. (in Russ.).

68. Patent 7071326 B2 (US). 2006.

69. Utkina E.I., Romanova S.M., Shipina O.T. Mezhdunarodnaia konferentsiia po khimicheskoi tekhnologii (posviashchaetsia 100-letiiu so dnia rozhdeniia akademika N.M. Zhavoronkova). [International Conference on Chemical Technology (dedicated to the 100th anniversary of the birth of Academician N.M. Zhavoronkov)]. Moscow, 2007, pp. 177-180. (in Russ.).

70. Panchenko O.A., Shushakova M.V., Karelin A.S. Novye dostizheniia v khimii i khimicheskoi tekhnologii rastitel'nogo syr'ia: materialy IV Vserossiiskoi konferentsii. [New achievements in chemistry and chemical technology of plant raw materials: materials of the IV All-Russian Conference]. Barnaul, 2009, vol. 1, pp. 104-106. (in Russ.).

71. Srinivasan K. S. V., Hon D. N.-S., Santappa M. ACS Symposium series «Graft Copolymerization of Lignocellulosic Fibers», American Chemical Society, Washington DC, 1982, pp. 155-178.

72. Patent H047318 A (JP). 1992.

73. Kozlova A.F., Snezhko V.A., Khomykov K.P. Izvestiia vuzov. Khimiia i khimicheskaia tekhnologiia, 1974, vol. 17, pp. 1890-1891. (in Russ.).

74. Kozlova A.F., Komar V.P., Petrova T.N., Virnik A.D. Cell. C. and technol., 1976, vol. 17, pp. 3-16. (in Russ.). 